\title{
Heteroleptic Amidinate Complexes of Heavy Group 15 Elements - Synthesis, X-Ray Crystal Structures and Theoretical Calculations
}

\author{
Benjamin Lyhs, ${ }^{[a]}$ Stephan Schulz, ${ }^{[a]} *$ Ulrich Westphal, ${ }^{[a]}$ Dieter Bläser, ${ }^{[a]}$ Roland Boese, ${ }^{[a]}$ \\ Michael Bolte, ${ }^{[b]}$
}

Dedicated to Prof. Dietmar Seyferth on the occasion of 80th birthday

Keywords: N ligands / Main group elements / Antimony / Bismuth / X-Ray diffraction

Mono-substituted amidinate complexes $\left[\mathrm{RC}\left(\mathrm{NR}^{\prime}\right)_{2}\right] \mathrm{ECl}_{2}(\mathrm{E}=\mathrm{Sb}, \mathrm{R}$ $=t-\mathrm{Bu}, \mathrm{R}^{\prime}=i-\operatorname{Pr} 1, \mathrm{Cy} 2,2,6-i-\mathrm{Pr}_{2}-\mathrm{C}_{6} \mathrm{H}_{3}$ (Dipp) 3; $\mathrm{R}=n-\mathrm{Bu}, \mathrm{R}^{\prime}=i-$ $\operatorname{Pr} 4 ; \mathrm{E}=\mathrm{Bi}, \mathrm{R}=t$-Bu, $\mathrm{R}^{\prime}=i$-Pr 5, Dipp 6) were prepared in high yields by salt elimination reactions of $\mathrm{ECl}_{3}$ with $\mathrm{Li}$-amidinates. $\mathbf{1}-$ $\mathbf{6}$ were characterized by elemental analyses, NMR and IR spectros- copy and single crystal X-ray diffraction. In addition, computational calculations were performed to clarify the different bonding modes in $\mathbf{1}$ and $\mathbf{5}$.

(C) WILEY-VCH Verlag GmbH \& Co. KGaA, 69451 Weinheim, Germany, 2009) [a] Institute of Inorganic Chemistry, University of Duisburg-Essen, 45117 Essen, Germany

Fax: + 49 0201-1834635

E-mail: stephan.schulz@uni-due.de

[b] Institute of Inorganic Chemistry, University of Frankfurt, 60438 Frankfurt, Germany

․ Supporting information for this article is available on the WWW under http://www.eurjic.org/ or from the author.

\section{Introduction}

$\mathrm{N}, \mathrm{N}^{\prime}$-chelating organic ligands $\mathrm{L}$ such as $\beta$-diketiminate $\mathbf{I}^{[1]}$ guanidinate $\mathbf{I I}^{[2]}$ and amidinate anions $\mathbf{I I I}^{[3]}$ have attracted growing interest in organometallic chemistry in the last decade due to their capability to coordinate very flexible to the metal center as monodentate $\left(\eta^{l}, \mathbf{a}\right)$, chelating $\left(\eta^{2}, \mathbf{b}\right)$ or bridging monodentate $\left(\mu-\eta^{l}-\eta^{l}\right.$, c) four-electron donor. ${ }^{[4]}$ Moreover, they were found very useful in catalysis, material sciences (i.e. precursors for CVD) and organic-inorganic hybrids since their steric and electronic properties can easily be tuned by modification of the organic substituents R and R'.<smiles>[R]N=C=CC=N[R]</smiles>

$\beta$-diketimininate I<smiles>[R]N=C(N[R])N[R]</smiles>

guanidinate II

R, R' = alkyl, aryl, $\mathrm{SiMe}_{3}$<smiles>[R]N=C([R])N[R]</smiles>

amidinate III
Scheme 1. Typical N,N' chelating ligands.

In main group element chemistry, research has mainly focused on the synthesis of group 13 element complexes. In particular monosubstituted complexes of the type $\mathrm{LMX}_{2}(\mathrm{M}=\mathrm{Al}, \mathrm{Ga}, \mathrm{In}, \mathrm{X}=$ halide, $\mathrm{Me}$ ) were found to be suitable starting reagents in olefin polymerization reactions and for the synthesis of low-valent group
13 metal complexes of the type LM $(\mathrm{M}=\mathrm{Al}, \mathrm{Ga}, \mathrm{In}),{ }^{[5]}$ in which the metal atom formally adopts the oxidation state $+\mathrm{I}$. The same was found for group $2(\mathrm{Mg})$ and group 14 metal complexes, in particular LGeX, which were found to be valuable precursors for the synthesis of the corresponding low-valent organomagnesium complexes of the type LMg-MgL ( $\mathrm{L}=\operatorname{ArNC}\left(\mathrm{N} i-\mathrm{Pr}_{2}\right) \mathrm{NAr}$ (Priso), $[\text { DippNC(Me) }]_{2} \mathrm{CH}$ (Dippnacnac) $)^{[6]}$ as well as $\mathrm{Ge}(\mathrm{I})$ complexes. ${ }^{[7]}$<smiles>[R]N=C([R])N([M])P</smiles>

a<smiles></smiles>

b<smiles>[R]C(N([R])[M])=[N+]([R])[M]</smiles>

C
Scheme 2. General coordination modes of amidinate ligands.

Due to our long-term interest in organobismuth and organoantimony chemistry, ${ }^{[8]}$ we became interested in the synthesis of complexes of the type $\mathrm{LECl}_{2}(\mathrm{E}=\mathrm{Sb}, \mathrm{Bi})$ containing $\mathrm{N}, \mathrm{N}^{\prime}-$ chelating substituents. To our surprise, only a very few group 15 element complexes of types I - III have been reported in the literature, in particular those of the heaviest elements, $\mathrm{Sb}$ and $\mathrm{Bi}^{\left[{ }^{[9]}\right.}$ Only very recently, a very few amidinate, ${ }^{[10]}$ formamidinate ${ }^{[11]}$ and $\beta$-diketiminate ${ }^{[12]}$ complexes have been structurally characterized. Moreover, reduction reaction in a very few cases also yielded lowvalent amidodiarsene ${ }^{[10]}$ and an unusual $\beta$-diiminato arsenic complex. ${ }^{[13]}$

In an attempt to synthesize potential starting reagents for further reactivity studies, we started to investigate salt elimination reaction between $\mathrm{ECl}_{3}(\mathrm{E}=\mathrm{Sb}, \mathrm{Bi})$ and $\mathrm{Li}$ amidinates. Herein, we report on the synthesis of six $\mathrm{Sb}$ and $\mathrm{Bi}$ amidinate complexes of the general type $\mathrm{LECl}_{2}$ and their X-ray crystal structures. 


\section{Results and Discussion}

Reactions of equimolar amounts of $\mathrm{ECl}_{3}(\mathrm{E}=\mathrm{Sb}, \mathrm{Bi})$ and $\mathrm{Li}\left[\mathrm{RC}\left(\mathrm{NR}^{\prime}\right)_{2}\right]\left(\mathrm{R}=n\right.$-Bu, $t$-Bu; $\mathrm{R}^{\prime}=i$-Pr, $\mathrm{Cy}$, Dipp $)$ in $\mathrm{Et}_{2} \mathrm{O}$ yielded the corresponding mono-substituted amidinate complexes of the general type $\left[t-\mathrm{BuC}\left(\mathrm{NR}^{\prime}\right)_{2}\right] \mathrm{SbCl}_{2}\left(\mathrm{R}^{\prime}=i\right.$-Pr 1, Cy 2, Dipp 3), $[n-$ $\left.\mathrm{BuC}(\mathrm{N} i-\mathrm{Pr})_{2}\right] \mathrm{SbCl}_{2} 4$, and $\left[t-\mathrm{BuC}\left(\mathrm{NR}^{\prime}\right)_{2}\right] \mathrm{BiCl}_{2}\left(\mathrm{R}^{\prime}=i-\operatorname{Pr}\right.$ 5, Dipp 6), respectively. Complexes $\mathbf{1}-\mathbf{6}$ were isolated after standard workup in high yields.

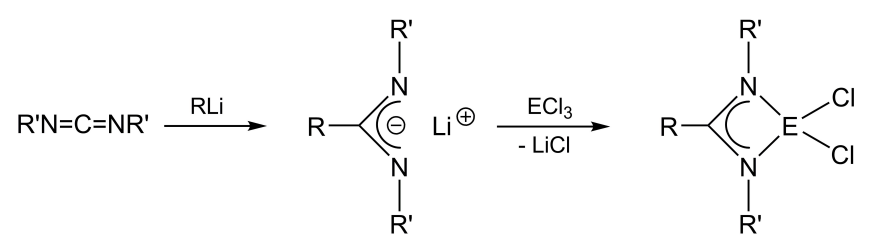

$\mathrm{E}=\mathrm{Sb}, \mathrm{R}=t-\mathrm{Bu}, \mathrm{R}^{\prime}=i-\operatorname{Pr} 1$, Cy 2, Dipp 3

$\mathrm{E}=\mathrm{Sb}, \mathrm{R}=n-\mathrm{Bu}, \mathrm{R}^{\prime}=i-\operatorname{Pr} 4$

$\mathrm{E}=\mathrm{Bi}, \mathrm{R}=t-\mathrm{Bu}, \mathrm{R}^{\prime}=i-\operatorname{Pr} 5$, Dipp 6

Scheme 3. Synthesis of mono-substituted amidinate complexe 1 - 6.

${ }^{1} \mathrm{H}$ and ${ }^{13} \mathrm{C}$ NMR spectra of $\mathbf{1}$ - $\mathbf{6}$ show the expected resonances due to the organic substituents $\left(\mathrm{R}, \mathrm{R}^{\prime}\right)$ of the amidinate moiety. The formation of solvent-coordinated $\left(\mathrm{Et}_{2} \mathrm{O}\right)$ complexes as was previously observed for comparable bismuth formamidinates of the type $\mathrm{LBiX}_{2}(\mathrm{X}=\mathrm{Cl}, \mathrm{Br})$ can be excluded for $\mathbf{1}-\mathbf{6} .^{[11]}$ Single crystals were obtained from solutions in $\mathrm{CHCl}_{3}(\mathbf{1}-\mathbf{5})$ and THF (6) after storage at $-30{ }^{\circ} \mathrm{C}$ for $48 \mathrm{~h}$.

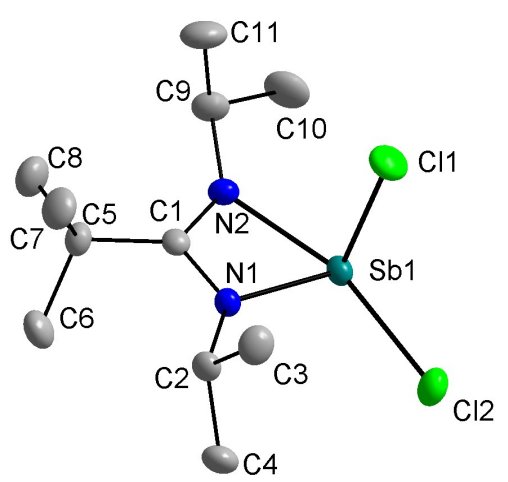

Figure 1. Molecular structure and atom numbering scheme of a monomeric unit of $t$ - $\mathrm{BuC}(\mathrm{N} i-\mathrm{Pr})_{2} \mathrm{SbCl}_{2} \mathbf{1}$; thermal ellipsoids are drawn at the $50 \%$ probability level. Hydrogen atoms have been omitted for clarity.

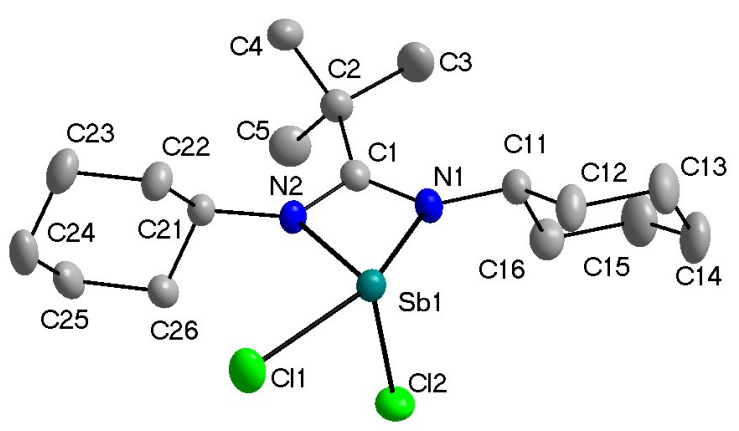

Figure 2. Molecular structure and atom numbering scheme of a monomeric unit of $t$ - $\mathrm{BuC}(\mathrm{NCy})_{2} \mathrm{SbCl}_{2} 2$; thermal ellipsoids are drawn at the $50 \%$ probability level. Hydrogen atoms have been omitted for clarity.
The complexes crystallize in the monoclinic space groups $P 2_{1} / \mathrm{c}$ (1) and $P 2_{1} / \mathrm{n}(\mathbf{2}, \mathbf{6})$, in the orthorhombic space group Pna ${ }_{1}(\mathbf{3})$ and in the triclinic space group $P-1(\mathbf{4}, \mathbf{5}) . \mathbf{3}, \mathbf{4}$, and 5 contain $\mathrm{CHCl}_{3}$ molecules in the crystal lattice whereas $\mathbf{1}$ and $\mathbf{2}$ were obtained as solvent-free complexes. In contrast, the Bi center in $\mathbf{6}$ is weakly coordinated by a THF donor and the crystal lattice contains two additional THF molecules. The amidinate moieties in $\mathbf{1}$ - $\mathbf{6}$ serve as chelating $\left(\eta^{2}\right)$ four-electron donor ligands. The N1-Sb1-N2 $\left(60.69(6)^{\circ} \mathbf{1} ; 60.41(6)^{\circ} \mathbf{2} ; 59.21(8)^{\circ} \mathbf{3} ; 60.99(10)^{\circ} 4\right)$ and N1-Bi1$\mathrm{N} 2$ bite angles $\left(58.43(18)^{\circ} 5\right.$ ) are close to $60^{\circ}$ as is typical for metal amidinate complexes whereas that of $\mathbf{6}$ shows a larger deviation $\left(55.69(11)^{\circ} \mathbf{6}\right)$. The N1-C1-N2 angles of $\mathbf{1}-\mathbf{6}$ are almost identical and the sum of bond angles at $\mathrm{C} 1(360.0 \mathbf{1}, \mathbf{2}, \mathbf{3}, \mathbf{4}, \mathbf{6} ; 359.8 \mathbf{5}), \mathrm{N} 1$ $(360.0 \mathbf{1} ; 359.62,3 ; 356.84 ; 359.95 ; 358.3 \mathbf{6})$ and $\mathrm{N} 2$ (359.2 1; $360.02 ; 355.43 ; 359.94,359.15,359.56)$ indicate $\mathrm{sp}^{2}$-hybridized carbon and nitrogen atoms. However, the delocalization of the $\pi$ electrons in the amidinate backbone of 1, 2, 3, 4 and $\mathbf{6}$ is distorted as expressed by the different $\mathrm{C} 1-\mathrm{N} 1 / 2$ bond lengths. Comparable findings were previously observed in amidinate and guanidinate complexes of the type $\mathrm{LECl}_{2}(\mathrm{E}=\mathrm{As}, \mathrm{Sb}) \cdot{ }^{[10,9 \mathrm{a}]}$ In contrast, 5 shows identical $\mathrm{C}-\mathrm{N}$ bond lengths, indicating almost perfectly delocalized $\pi$-electrons as was reported for $\left[\mathrm{PhC}(\mathrm{NMe})_{2} \mathrm{ECl}_{4}(\mathrm{E}=\right.$ $\mathrm{As}, \mathrm{Sb})^{[14]}$ and $\left[\mathrm{PhC}(\mathrm{NMe})_{2} \mathrm{Sb}(\mathrm{Ph})_{2} \mathrm{Cl}_{2} \cdot{ }^{[15]}\right.$ In addition, the E1-N1 and E1-N2 bond lengths of $\mathbf{1}-\mathbf{4}$ and $\mathbf{6}$ differ significantly, whereas in 5 almost identical Bi-N bond distances were observed. Moreover, the most striking structural difference between $\mathbf{1}-\mathbf{4}$ and $\mathbf{6}$ on one hand and $\mathbf{5}$ on the other hand is reflected by the exocyclic Cl1-E1$\mathrm{Cl} 2$ bond angles, which are significantly smaller in $\mathbf{1}-\mathbf{4}$ and $\mathbf{6}$ compared to the almost linear orientation (C11-Bi1-Cl2 $\left(175.02(5)^{\circ}\right)$ as observed in $\mathbf{5}$.

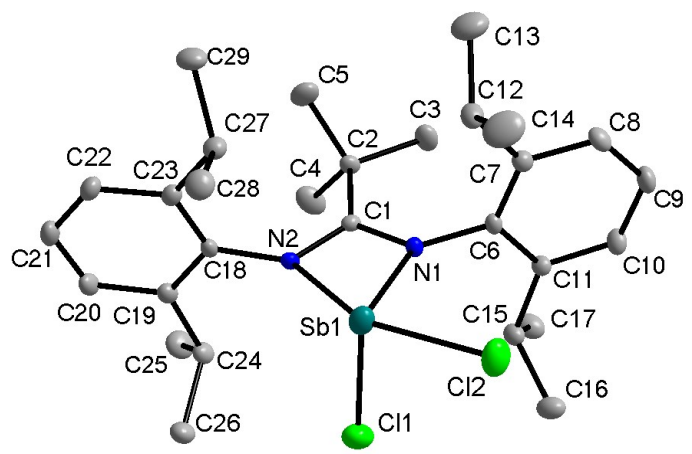

Figure 3. Molecular structure and atom numbering scheme of $t$ BuC(NDipp) ${ }_{2} \mathrm{SbCl}_{2} 3$; thermal ellipsoids are drawn at the $50 \%$ probability level. Hydrogen atoms and $\mathrm{CHCl}_{3}$ molecules have been omitted for clarity.

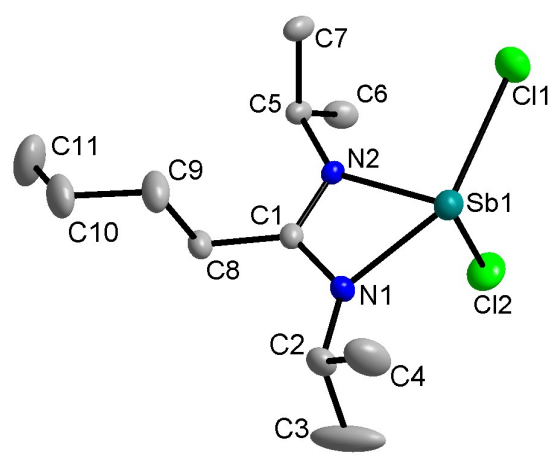

Figure 4. Molecular structure and atom numbering scheme of $n$ - BuC(Ni$\mathrm{Pr})_{2} \mathrm{SbCl}_{2} 4$; thermal ellipsoids are drawn at the $50 \%$ probability level. Hydrogen atoms and $\mathrm{CHCl}_{3}$ molecules have been omitted for clarity. 


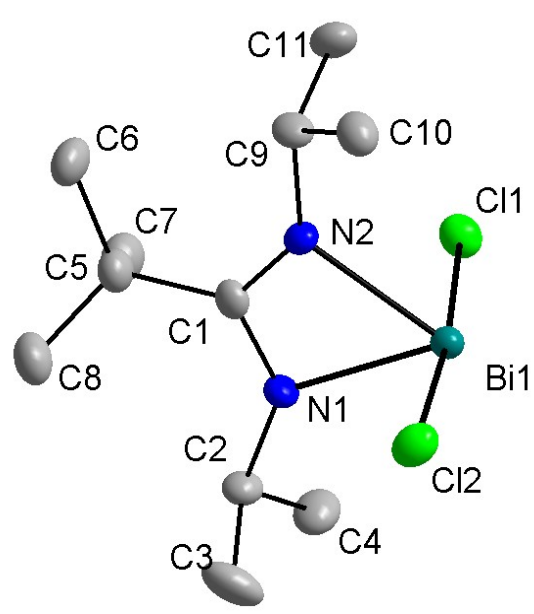

Figure 5. Molecular structure and atom numbering scheme of a monomeric unit of $t$ - $\mathrm{BuC}(\mathrm{N} i-\mathrm{Pr})_{2} \mathrm{BiCl}_{2} \mathbf{5}$; thermal ellipsoids are drawn at the $50 \%$ probability level. Hydrogen atoms and $\mathrm{CHCl}_{3}$ molecules have been omitted for clarity.

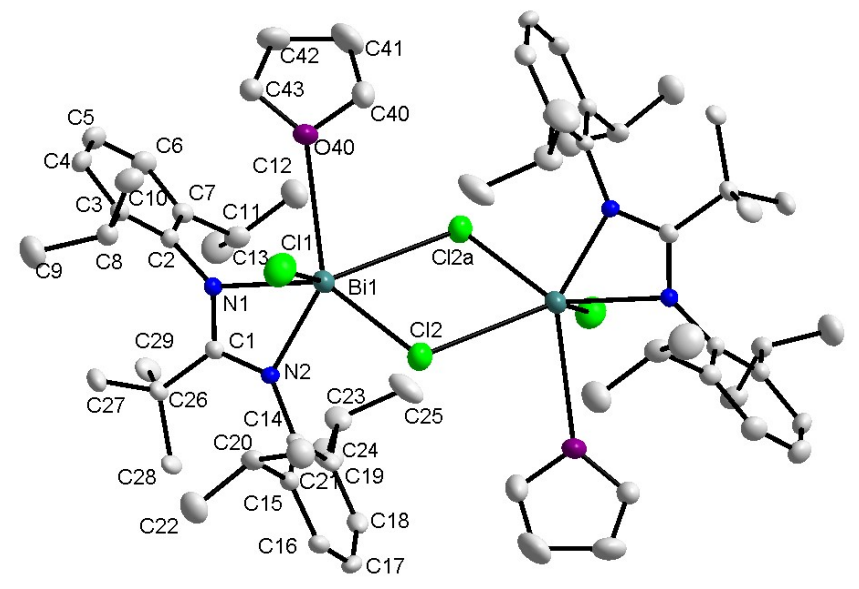

Figure 6. Molecular structure and atom numbering scheme of the dimer of $t$-BuC(NDipp) ${ }_{2} \mathrm{BiCl}_{2} 6$; thermal ellipsoids are drawn at the $50 \%$ probability level. Hydrogen atoms and additional THF molecules have been omitted for clarity.

The coordination geometry observed for $\mathbf{1}-\mathbf{4}$ can either be described as heavily distorted "saw-horse" or as distorted trigonal bypyramidal conformation with the stereochemically active electron lone pair at the $\mathrm{Sb}$ atom adopting an equatorial position as was previously observed for group 15 formamidinate complexes. ${ }^{[11]}$ As a consequence, the axial Sb-Clax $(2.6435(6)$ 1; 2.6114(6) 2; 2.4732(7) 3; 2.6735(9) $\AA$ 4) and Sb-Nax bond lengths (2.1906(16) 1 ; 2.2204(17) 2; 2.3059(19) 3; 2.205(3) $\AA$ 4) are significantly elongated compared to the equatorial $\mathrm{Sb}-\mathrm{Cl}_{\mathrm{eq}}$ $\left(2.4030(6) 1 ; 2.3982(6) 2 ; 2.3664(8) 3 ; 2.4127(9) \AA 4\right.$ ) and $\mathrm{Sb}-\mathrm{N}_{\mathrm{eq}}$ distances $(2.1011(16) 1,2.1022(16) 2 ; 2.104(2) 3 ; 2.116(2) \AA 4)$. The $\mathrm{Cl}_{\mathrm{ax}}-\mathrm{Sb} 1-\mathrm{N}_{\mathrm{ax}}$ axes $\left(152.46(5)^{\circ} \mathbf{1} ; 153.58(5)^{\circ} \mathbf{2} ; 147.81(6)^{\circ} \mathbf{3}\right.$; $\left.152.19(8)^{\circ} 4\right)$ significantly deviate from linearity due to the larger steric demand of the electron lone pair.

In remarkable contrast to $\mathbf{3}$, which is a monomeric complex in the solid state, solvent-free complexes 1 and $\mathbf{2}$ as well as $\mathbf{4}$, which contains a $\mathrm{CHCl}_{3}$ molecule in the crystal lattice, show weak intermolecular interactions between the axial $\mathrm{Cl}$ atom $(\mathrm{Cl} 2 \mathbf{1}, \mathrm{Cl1} 2$ $\mathrm{Cl1} 4$ ) and an adjacent $\mathrm{Sb}^{\prime}$ atom, resulting in the formation of asymmetric $\mathrm{Sb}-\mathrm{Cl}-\mathrm{Sb}^{\prime}$ bridges. The $\mathrm{Sb}-\mathrm{Cl}$ bond lengths are significantly elongated $(3.1171(7) \mathbf{1}, 3.2447(6) 2,3.1195(9) \AA 4)$ compared to the $\mathrm{Sb}-\mathrm{Cl}$ bonds $(2.6435(6) 1 ; 2.6114(6) 2 ; 2.6735(9)$ $\AA$ 4), but far below the sum of the van der waals radii (4.01 $\AA$ ) and within the range typically observed for anionic chloridoantimonides $\mathrm{Sb}_{2} \mathrm{Cl}_{8}{ }^{2-}, \mathrm{Sb}_{2} \mathrm{Cl}_{10}{ }^{4-}, \mathrm{Sb}_{2} \mathrm{Cl}_{11}{ }^{5-}$, and $\mathrm{Sb}_{4} \mathrm{Cl}_{16} 6^{4-}{ }^{-[16]}$

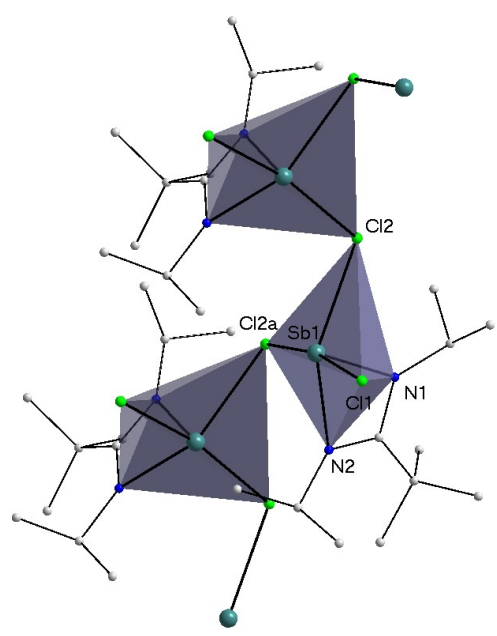

Figure 7. Ball-and-stick/polyhedral presentation of 1. Hydrogen atoms not shown for clarity.

The $\mathrm{Sb}$ '- $\mathrm{Cl}$ distances between the second (equatorial) $\mathrm{Cl}$ atom and the adjacent $\mathrm{Sb}^{\prime}$ atom in $\mathbf{1}$ and $\mathbf{2}$ are significantly longer (4.7343(7) 1, 6.5652(6) § 2), whereas 4 shows a second weak interaction (3.8972(12) $\AA$ ). Consequently, $\mathbf{1}$ and $\mathbf{2}$ are best described as corner-bridged oligomers, whereas $\mathbf{4}$ forms an edgebridged oligomer. An even more regular structure is observed for $\mathbf{5}$, which shows two almost equal intermolecular $\mathrm{Cl} 1 / 2-\mathrm{Bi}^{\prime}$ bond distances (3.1746(17), 3.2102(19) $\AA$ ). Even though these bond lengths are elongated compared to the "regular" $\mathrm{Bi}-\mathrm{Cl}$ distances (2.7399(18), 2.6868(18) $\AA$ ), 5 is more symmetric than the dimeric complex $\left\{\left[2-(6-\mathrm{Mepy}) \mathrm{NSiMe}_{3}\right]_{2} \mathrm{BiCl}\right\}_{2}\left(\mathrm{Bi}^{\prime}-\mathrm{Cl}\right.$ 2.629(4), 3.554(6) $\AA) .{ }^{[17 b]}$ As a structural consequence, the coordination geometry of Bi atoms in $\mathbf{5}$ can be described as distorted octahedral.

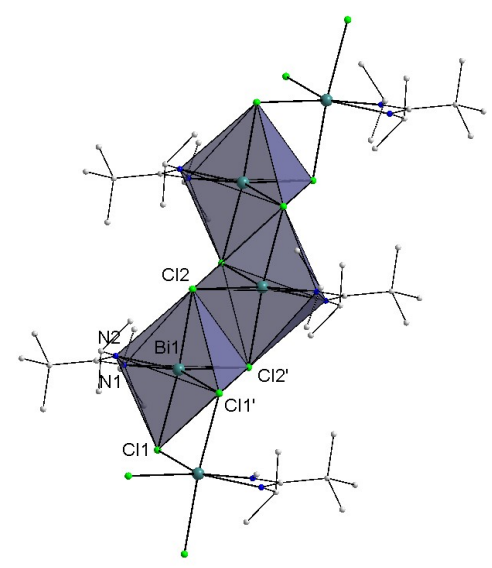

Figure 8. Ball-and-stick/polyhedral presentation of 5. Hydrogen atoms not shown for clarity.

The distortion most likely results from the small bite angle (N-C$\mathrm{N})$ of the amidinate moiety, which deviates significantly from the $90^{\circ}$ as expected for a regular octahedron. The octahedrons form an 
edge-shared polymeric structure in the solid state. The electron lone pair at the $\mathrm{Bi}$ atom is stereochemically inert, which is in remarkable contrast to $\mathbf{1} \mathbf{- 4}$. The structure of $\mathbf{5}$ significantly differs from thf-coordinated, dimeric $\mathbf{6}$ (Cl-Bi' 3.4398(10) $\AA$ ) and from solvent-coordinated mono-substituted formamidinates of the type $\mathrm{LBiCl}_{2}$ (thf) and $\left[\mathrm{LBiBr}_{2} \text { (thf) }\right]_{2}$ as recently reported by Jones et al., ${ }^{[11]}$ which either form centrosymmetric dimers $\left(\left[\operatorname{LBiBr}_{2}(\text { thf })\right]_{2}\right)$ or adopt a trimeric structure $\left(\mathrm{LBiCl}_{2}(\mathrm{thf})\right)$ with bridging and terminal $\mathrm{Cl}$ atoms. The $\mathrm{Bi}-\mathrm{X}-\mathrm{Bi}$ bridges $(\mathrm{X}=\mathrm{Br}, \mathrm{Cl})$ of these formamidinate complexes are asymmetrical and the $\mathrm{Bi}-\mathrm{X}$ distances range from $2.9-3.1 \AA(\mathrm{X}=\mathrm{Br})$ and $2.5-3.7 \AA(\mathrm{X}=\mathrm{Cl})$ as was observed for 6 .

The structural parameters as observed for $\mathbf{1}$ - $\mathbf{6}$ point to a rather strong influence of both the steric demand of the amidinate ligands as well as the nature of the solvent. $\mathbf{3}$, which contains the sterically most demanding amidinate substituent, forms a monomeric structure, whereas $\mathbf{4}$, which is sterically slightly less hindered than the analogous $t$-Bu substituted corner-bridged complex 1 forms an edge-bridged oligomeric structure. Coordination of a donor solvent prevents the formation of oligomeric structures as was previously observed for comparable formamidinate complexes. ${ }^{[1]}$

Theoretical calculations were performed in order to elucidate the different structures of $\mathbf{1}$ and $\mathbf{5}$, in particular their different intermolecular interactions and, as a consequence, their different coordination geometries. ${ }^{[18]}$ Moreover, the electronic nature of the electron lone pair was investigated in more detail. Computational calculations starting with the experimental structural data were performed both with the monomeric $(\mathbf{1} \mathbf{a}, \mathbf{5 a})$ and trimeric units $(\mathbf{1 b}$ 1c, 5b), which represents a small cut of the weakly associated oligomeric complexes. The calculated structural parameters of the trimeric complexes $\mathbf{1 b}$ and $\mathbf{5 b}$ agree slightly better with the experimental values as obtained for $\mathbf{1}$ and $\mathbf{5}$ than those of the monomeric complexes 1a and 5a. In particular the $\mathrm{Cl}-\mathrm{Bi}-\mathrm{Cl}$ bond angle of the trimer $\mathbf{5 b}\left(179^{\circ}\right)$ agrees much better with the experimentally observed bond angle $\left(175.02(5)^{\circ}\right)$. The $\mathrm{Sb}-\mathrm{N}$ and $\mathrm{Sb}-\mathrm{Cl}$ bond lengths are typically slightly overestimated whereas the intermolecular $\mathrm{Bi}^{\prime}-\mathrm{Cl}$ bond length in $\mathbf{5 b}$ is slightly shorter compared to the experimental value as observed in 5. Surprisingly, the calculated structure of symmetrically bridged $1 \mathbf{c}$, which was obtained using the experimental data of $\mathbf{5}$ as starting point for the structure optimization, is energetically favored by $12 \mathrm{kcal} / \mathrm{mol}(4$ $\mathrm{kcal} / \mathrm{mol} /$ monomeric unit) compared to $\mathbf{1 b}$. Moreover, the scharacter of the electron lone pair of the central $\mathrm{Sb}$ atom in 1c $(93.2 \%)$ is higher than that in $\mathbf{1 b}(87 \%)$ and in the monomeric complex 1a (87.5\%). However, these values are still below those calculated for the Bi complexes $(\mathbf{5 a}, 94 \% ; \mathbf{5 b}, 97 \%)$. According to these calculations, the electron lone pair of the $\mathrm{Bi}$ complex is less stereochemically active compared to that of the Sb complex, which agrees very well with the different coordination modes as experimentally observed in the solid state structures of $\mathbf{1}$ and $\mathbf{5}$.

\section{Conclusions}

Six mono-substituted amidinate complexes $\left[\mathrm{RC}\left(\mathrm{NR}^{\prime}\right)_{2}\right] \mathrm{ECl}_{2}$ of the heaviest group 15 metals $(\mathrm{Sb}, \mathrm{Bi})$ have been prepared and structurally characterized. The central metal ( $\mathrm{Sb}, \mathrm{Bi})$ as well as the solvent and the steric demand of the amidinate substituent, which can be adjusted by use of different groups $\mathrm{R}(n-\mathrm{Bu}, t-\mathrm{Bu})$ and $\mathrm{R}^{\prime}(i-$ $\mathrm{Pr}, \mathrm{Cy}$, Dipp), show a distinguished influence to the coordination geometry of the resulting complexes.

\section{Experimental Section}

General Procedures. All manipulations were performed under an argon atmosphere using standard Schlenk techniques or in an inert atmosphere glove box. Solvents were dried over $\mathrm{Na} / \mathrm{K}\left(\mathrm{Et}_{2} \mathrm{O}\right)$ and $\mathrm{CaH}_{2}\left(\mathrm{CHCl}_{3}\right)$ and degassed prior to use. ${ }^{1} \mathrm{H}$ and ${ }^{13} \mathrm{C}\left\{{ }^{1} \mathrm{H}\right\}$ NMR spectra were recorded on a Bruker Avance 500 spectrometer and are referenced to internal $\mathrm{CDCl}_{3}\left({ }^{1} \mathrm{H}\right.$ : $\left.\delta=7.24 ;{ }^{13} \mathrm{C}: \delta=77.0\right)$. $\mathrm{SbCl}_{3}$ and $\mathrm{BiCl}_{3}$ were commercially available and used after purification (sublimation). Li-amidinates $\mathrm{Li}\left[\mathrm{RC}\left(\mathrm{NR}^{\prime}\right)_{2}\right]$ were generally prepared by reaction of a carbodiimide with the corresponding organolithium compound. IR spectra were recorded on a ALPHA-T FT-IR spectrometer equipped with a single reflection ATR sampling module.

Melting points were measured in sealed capillaries and were not corrected. Elemental analyses were performed at the Elementaranalyse Labor of the University of Essen.

General Preparation of $\mathbf{L E C l}_{\mathbf{2}}(\mathrm{L}=$ amidinate, $\mathbf{E}=\mathbf{S b}, \mathbf{B i})$ : Solid $\mathrm{Li}\left[\mathrm{RC}\left(\mathrm{NR}^{\prime}\right)_{2}\right]\left(\mathrm{R}=n\right.$-Bu, $t$-Bu; $\mathrm{R}^{\prime}=i$-Pr, Cy, Dipp) was slowly added within $1 \mathrm{~h}$ to a solution of $\mathrm{ECl}_{3}$ in $50 \mathrm{~mL}$ of $\mathrm{Et}_{2} \mathrm{O}$ at $-78^{\circ} \mathrm{C}$, stirred for $1 \mathrm{~h}$ and then warmed to ambient temperature over a period of $6 \mathrm{~h}$. The resulting precipitate was filtered and extracted two times with $\mathrm{CHCl}_{3}(40 \mathrm{~mL})$. The solvent was evaporated in vacuum, yielding grey $(\mathrm{E}=\mathrm{Sb})$ and yellowish crystalline solids $(\mathrm{E}=\mathrm{Bi})$, respectively.

[t -BuC(Ni-Pr) $)_{2}$ ]SbCl $\mathbf{S b}_{2}$ 1. $t$-BuC(Ni-Pr) $)_{2} \mathrm{Li}(2.50 \mathrm{~g}, 13.14 \mathrm{mmol}), \mathrm{SbCl}_{3}$ ( $3.00 \mathrm{~g}, 13.14 \mathrm{mmol})$. Yield $3.98 \mathrm{~g}$ (10.59 mmol, 81\%). Melting point: $144{ }^{\circ} \mathrm{C}$. Elemental Analysis $\mathrm{C}_{11} \mathrm{H}_{23} \mathrm{~N}_{2} \mathrm{SbCl}_{2}(375.97 \mathrm{~g} / \mathrm{mol})$ : found (calcd): H, 6.07 (6.17); C, 35.01 (35.14); N, 7.32 (7.45) \%. ${ }^{1} \mathrm{H}$ NMR (300 MHz, $\left.\mathrm{CDCl}_{3}, 25^{\circ} \mathrm{C}\right): \delta 1.40\left(\mathrm{~d},{ }^{3} \mathrm{~J}_{\mathrm{HH}}=6.6 \mathrm{~Hz}, 12 \mathrm{H}, \mathrm{CH}\left(\mathrm{CH}_{3}\right)_{2}\right), 1.45(\mathrm{~s}, 9 \mathrm{H}, t-\mathrm{Bu})$, $4.61\left(\mathrm{sep},{ }^{3} \mathrm{~J}_{\mathrm{HH}}=6.6 \mathrm{~Hz}, 2 \mathrm{H}, \mathrm{CH}\left(\mathrm{CH}_{3}\right)_{2}\right) .{ }^{13} \mathrm{C} \mathrm{NMR}\left(75 \mathrm{MHz}, \mathrm{CDCl}_{3}\right.$, $\left.25^{\circ} \mathrm{C}\right): \delta 24.1(\mathrm{CHMe}), 29.4\left(\mathrm{CMe}_{3}\right), 40.8\left(\mathrm{CMe}_{3}\right), 48.9\left(\mathrm{CHMe}_{2}\right), 176.6$ $\left(C \mathrm{~N}_{2}\right)$. IR: v 3013, 2964, 2931, 2871, 1493, 1474, 1381, 1362, 1311, 1186 , $1115,1052,1023,926,797,676,558,491,443,413 \mathrm{~cm}^{-1}$.

$\left.[\boldsymbol{t} \text {-BuC(NCy })_{2}\right] \mathbf{S b C l}_{2} 2 . t$-BuC(NCy $)_{2} \mathrm{Li}(2.50 \mathrm{~g}, 9.25 \mathrm{mmol}), \mathrm{SbCl}_{3}(2.11 \mathrm{~g}$, $9.25 \mathrm{mmol})$. Yield $3.29 \mathrm{~g}$ (7.22 mmol, $78 \%$ ). Melting point: $205^{\circ} \mathrm{C}$ (dec.). Elemental Analysis $\mathrm{C}_{17} \mathrm{H}_{31} \mathrm{~N}_{2} \mathrm{SbCl}_{2}(456.10 \mathrm{~g} / \mathrm{mol})$ : found (calcd): $\mathrm{H}, 6.72$ (6.85); C, 44.57 (44.77); N, 6.08 (6.14) \%. ${ }^{1} \mathrm{H} \mathrm{NMR} \mathrm{(500} \mathrm{MHz,} \mathrm{CDCl}_{3}$, $\left.25^{\circ} \mathrm{C}\right): \delta 1.16-1.87(\mathrm{~m}, 20 \mathrm{H}, \mathrm{NCy}), 1.44(\mathrm{~s}, 9 \mathrm{H}, t-\mathrm{Bu}), 4.11(\mathrm{~m}, 2 \mathrm{H}$, $\left.\mathrm{NCHC}_{5} \mathrm{H}_{10}\right) \cdot{ }^{13} \mathrm{C} \mathrm{NMR}\left(75 \mathrm{MHz}, \mathrm{CDCl}_{3}, 25{ }^{\circ} \mathrm{C}\right): \delta 24.9(\mathrm{C} 3 / \mathrm{C} 5) ; 25.8(\mathrm{C} 4)$, $29.4\left(\mathrm{CMe}_{3}\right), 34.5(\mathrm{C} 2 / \mathrm{C} 6), 41.2\left(\mathrm{CMe}_{3}\right), 57.2(\mathrm{~N}-\mathrm{C} 1), 177.8\left(\mathrm{CN}_{2}\right)$. IR: v 2962, 2924, 2847, 1595, 1518, 1452, 1425, 1405, 1377, 1341, 1309, 1299, $1259,1172,1015,889,865,795,712,660,629,484 \mathrm{~cm}^{-1}$.

[t -BuC(NDipp) $\left.)_{2}\right] \mathbf{S b C l}_{2}$ 3. $t$-BuC(NDipp) ${ }_{2} \mathrm{Li}(5.61 \mathrm{~g}, 13.14 \mathrm{mmol}), \mathrm{SbCl}_{3}$ (3.00 g, $13.14 \mathrm{mmol})$. Yield $5.88 \mathrm{~g}(9.61 \mathrm{mmol}, 73 \%)$. Melting point: $182{ }^{\circ} \mathrm{C}$. Elemental Analysis $\mathrm{C}_{29} \mathrm{H}_{43} \mathrm{~N}_{2} \mathrm{SbCl}_{2}(612.33 \mathrm{~g} / \mathrm{mol})$ : found (calcd): H, 7.05 (7.08); C, 56.87 (56.89); N, 4.51 (4.57) \%. ${ }^{1} \mathrm{H} \mathrm{NMR} \mathrm{(300} \mathrm{MHz,}$ $\left.\mathrm{CDCl}_{3}, 25{ }^{\circ} \mathrm{C}\right): \delta 0.98(\mathrm{~s}, 9 \mathrm{H}, t-\mathrm{Bu}), 1.30\left(\mathrm{~d},{ }^{3} \mathrm{~J}_{\mathrm{HH}}=6.6 \mathrm{~Hz}, 12 \mathrm{H}, \mathrm{CH}\left(\mathrm{CH}_{3}\right)_{2}\right)$, $1.34\left(\mathrm{~d},{ }^{3} \mathrm{~J}_{\mathrm{HH}}=6.9 \mathrm{~Hz}, 12 \mathrm{H}, \mathrm{CH}\left(\mathrm{CH}_{3}\right)_{2}\right), 3.30\left(\mathrm{~m}, 4 \mathrm{H}, \mathrm{CH}\left(\mathrm{CH}_{3}\right)_{2}\right), 7.18(\mathrm{~m}$, $6 \mathrm{H}, \mathrm{ArH}) .{ }^{13} \mathrm{C} \mathrm{NMR}\left(75 \mathrm{MHz}, \mathrm{CDCl}_{3}, 25{ }^{\circ} \mathrm{C}\right): \delta 23.0(\mathrm{CHMe}), 26.9$ $\left(\mathrm{CHMe}_{2}\right), 29.1\left(\mathrm{CMe}_{3}\right), 41.9\left(\mathrm{CMe}_{3}\right), 123.6(\mathrm{C} 4), 127.0(\mathrm{C} 3 / \mathrm{C} 5), 136.6$ $(\mathrm{C} 2 / \mathrm{C} 6), 144.9(\mathrm{~N}-\mathrm{C} 1), 174.8\left(\mathrm{CN}_{2}\right)$. IR: v 2962, 2929, 2868, 1522, 1437 , $1382,1362,1315,1254,1228,1175,1094,1007,798,784,761,714,663$, $435,401 \mathrm{~cm}^{-1}$.

[n-BuC(Ni-Pr) $)_{2} \mathbf{S b C l}_{2}$ 4. $n$-BuC(Ni-Pr $)_{2} \mathrm{Li}(2.50 \mathrm{~g}, 13.14 \mathrm{mmol}), \mathrm{SbCl}_{3}$ $(3.00 \mathrm{~g}, 13.14 \mathrm{mmol})$. Yield $4.10 \mathrm{~g}$ (10.91 mmol, 83\%). Melting point: $82{ }^{\circ} \mathrm{C}$. Elemental Analysis $\mathrm{C}_{11} \mathrm{H}_{23} \mathrm{~N}_{2} \mathrm{SbCl}_{2}(375.97 \mathrm{~g} / \mathrm{mol})$ : found (calcd): $\mathrm{H}$, 6.12 (6.17); C, 35.10 (35.14); N, 7.34 (7.45) \%. ${ }^{1} \mathrm{H} \mathrm{NMR}\left(300 \mathrm{MHz}, \mathrm{CDCl}_{3}\right.$, $\left.25^{\circ} \mathrm{C}\right): \delta 0.95\left(\mathrm{t},{ }^{3} \mathrm{~J}_{\mathrm{HH}}=7.2 \mathrm{~Hz}, 3 \mathrm{H}, \mathrm{CH}_{2} \mathrm{CH}_{2} \mathrm{CH}_{2} \mathrm{CH}_{3}\right), 1.30\left(\mathrm{~d},{ }^{3} \mathrm{~J}_{\mathrm{HH}}=6.6\right.$ $\left.\mathrm{Hz}, 12 \mathrm{H}, \mathrm{CH}\left(\mathrm{CH}_{3}\right)_{2}\right), 1.42\left(\mathrm{~m}, 2 \mathrm{H}, \mathrm{CH}_{2} \mathrm{CH}_{2} \mathrm{CH}_{2} \mathrm{CH}_{3}\right), 1.53(\mathrm{~m}, 2 \mathrm{H}$, $\left.\mathrm{CH}_{2} \mathrm{CH}_{2} \mathrm{CH}_{2} \mathrm{CH}_{3}\right), 2.30\left(\mathrm{~m}, 2 \mathrm{H}, \mathrm{CH}_{2} \mathrm{CH}_{2} \mathrm{CH}_{2} \mathrm{CH}_{3}\right), 4.04\left(\mathrm{sep},{ }^{3} \mathrm{~J}_{\mathrm{HH}}=6.6 \mathrm{~Hz}\right.$, $\left.2 \mathrm{H}, \mathrm{CH}\left(\mathrm{CH}_{3}\right)_{2}\right) .{ }^{13} \mathrm{C} \mathrm{NMR}\left(75 \mathrm{MHz}, \mathrm{CDCl}_{3}, 25{ }^{\circ} \mathrm{C}\right): \delta 13.7\left(\mathrm{CH}_{2}-\mathrm{CH}_{2}-\mathrm{CH}_{2}-\right.$ $\left.\mathrm{CH}_{3}\right), 22.9\left(\mathrm{CH}_{2}-\mathrm{CH}_{2}-\mathrm{CH}_{2}-\mathrm{CH}_{3}\right), 24.1(\mathrm{CHMe}), 27.1\left(\mathrm{CH}_{2}-\mathrm{CH}_{2}-\mathrm{CH}_{2}-\mathrm{CH}_{3}\right)$, $29.0\left(\mathrm{CH}_{2}-\mathrm{CH}_{2}-\mathrm{CH}_{2}-\mathrm{CH}_{3}\right), 47.8\left(\mathrm{CHMe}_{2}\right), 172.6\left(\mathrm{CN}_{2}\right)$. IR: v 2964, 2929, 2870, 1643, 1522, 1464, 1451, 1436, 1363, 1336, 1258, 1227, 1203, 1028, $1078,949,839,796,687,614,564,454,414 \mathrm{~cm}^{-1}$.

$\left.[\boldsymbol{t} \text {-BuC(Ni-Pr })_{2}\right] \mathbf{B i C l}_{2}$ 5. $t$-BuC(Ni-Pr $)_{2} \mathrm{Li}(2.50 \mathrm{~g}, 13.14 \mathrm{mmol}), \mathrm{BiCl}_{3}(4.15$ $\mathrm{g}, 13.14 \mathrm{mmol})$. Yield $4.57 \mathrm{~g}(9.86 \mathrm{mmol}, 75 \%)$. Melting point: $170{ }^{\circ} \mathrm{C}$ 
(dec.). Elemental Analysis $\mathrm{C}_{11} \mathrm{H}_{23} \mathrm{~N}_{2} \mathrm{BiCl}_{2}(463.20 \mathrm{~g} / \mathrm{mol})$ : found (calcd): $\mathrm{H}$, 5.12 (5.00); C, 28.47 (28.52); N, 5.80 (6.05) \%. ${ }^{1} \mathrm{H}$ NMR (300 MHz, CDCl 3 , $\left.25^{\circ} \mathrm{C}\right): \delta 1.35\left(\mathrm{~d},{ }^{3} \mathrm{~J}_{\mathrm{HH}}=6.2 \mathrm{~Hz}, 12 \mathrm{H}, \mathrm{CH}\left(\mathrm{CH}_{3}\right)_{2}\right), 1.53(\mathrm{~s}, 9 \mathrm{H}, t-\mathrm{Bu}), 6.77$ (sep, $\left.{ }^{3} \mathrm{~J}_{\mathrm{HH}}=6.2 \mathrm{~Hz}, 2 \mathrm{H}, \mathrm{CH}\left(\mathrm{CH}_{3}\right)_{2}\right) \cdot{ }^{13} \mathrm{C} \mathrm{NMR}\left(75 \mathrm{MHz}, \mathrm{CDCl}_{3}, 25{ }^{\circ} \mathrm{C}\right): \delta$ $25.9\left(\mathrm{CHMe} e_{2}\right), 29.8\left(\mathrm{CMe}_{3}\right), 48.2\left(\mathrm{CMe}_{3}\right), 52.8\left(\mathrm{CHMe}_{2}\right), 177.8\left(\mathrm{CN}_{2}\right)$. IR: v 2964, 2927, 2880,1615, 1489, 1452, 1409, 1368, 1311, 1183, 1115, 1046, $925,803,671,553,474 \mathrm{~cm}^{-1}$.

$\boldsymbol{t}$-BuC(NDipp) ${ }_{2} \mathbf{B i C l}_{2}$ 6. $t$-BuC(NDipp) $)_{2} \mathrm{Li}(5.61 \mathrm{~g}, 13.14 \mathrm{mmol}), \mathrm{BiCl}_{3}$ $(4.15 \mathrm{~g}, 13.14 \mathrm{mmol})$. Yield $7.25 \mathrm{~g}$ (10.36 mmol, 79\%). Melting point: $183{ }^{\circ} \mathrm{C}$ (dec.). Elemental Analysis $\mathrm{C}_{29} \mathrm{H}_{43} \mathrm{~N}_{2} \mathrm{BiCl}_{2}(699.56 \mathrm{~g} / \mathrm{mol})$ : found (calcd): H, 6.13 (6.19); C, 49.53 (49.79); N, 3.89 (4.00) \%. ${ }^{1} \mathrm{H}$ NMR (300 $\left.\mathrm{MHz}, \mathrm{CDCl}_{3}, 25^{\circ} \mathrm{C}\right): \delta 1.07(\mathrm{~s}, 9 \mathrm{H}, t-\mathrm{Bu}), 1.32\left(\mathrm{~d},{ }^{3} \mathrm{~J}_{\mathrm{HH}}=6.9 \mathrm{~Hz}, 12 \mathrm{H}\right.$, $\left.\mathrm{CH}\left(\mathrm{CH}_{3}\right)_{2}\right), 1.39\left(\mathrm{~d},{ }^{3} \mathrm{~J}_{\mathrm{HH}}=6.9 \mathrm{~Hz}, 12 \mathrm{H}, \mathrm{CH}\left(\mathrm{CH}_{3}\right)_{2}\right), 3.47(\mathrm{~m}, 4 \mathrm{H}$, $\left.\mathrm{CH}\left(\mathrm{CH}_{3}\right)_{2}\right), 7.09(\mathrm{~m}, 6 \mathrm{H}, \mathrm{ArH}) .{ }^{13} \mathrm{C} \mathrm{NMR}\left(75 \mathrm{MHz}, \mathrm{CDCl}_{3}, 25{ }^{\circ} \mathrm{C}\right): \delta 23.2$ $\left(\mathrm{CCMe}_{3}\right), 27.9\left(\mathrm{CHMe} e_{2}\right), 28.5(\mathrm{CHMe}), 29.7\left(\mathrm{CHMe}_{2}\right), 49.5\left(\mathrm{CCMe}_{3}\right)$, 123.1 (C4), 127.6 (C3/C5), 136.7 (C2/C6), 145.7 (N-C1), 172.8 ( $\left.\mathrm{CCMe}_{3}\right)$. IR: v 2959, 2864, 1616, 1433, 1362, 1316, 1258, 1213, 1173, 1091, 1013, $931,866,797,761,661,474,430,396 \mathrm{~cm}^{-1}$.

Single crystal X-ray analysis. Crystallographic data of $\mathbf{1}-\mathbf{6}$ are summarized in Table 1 and bond lengths and angles are given in Table 2. Figures $1-6$ show ORTEP diagrams of the solid state structures of $\mathbf{1}-\mathbf{6}$. Data were collected on a Bruker AXS SMART APEX CCD diffractometer, (Mo $\alpha$ radiation, $\lambda=0.71073 \AA ; T=173(2) \mathrm{K}$ ). The structures were solved by Direct Methods (SHELXS-97) ${ }^{[19]}$ and refined by full-matrix leastsquares on $\mathrm{F}^{2}$ (SHELXL-97, Program for Crystal Structure Refinement). ${ }^{[20]}$ Semi-empirical absorption corrections were applied.

Supporting Information: X-ray crystallographic data including a cif file of $\mathbf{1}-\mathbf{6}$, and tables of selected structural parameters, absolute energies and atomic charges of $\mathbf{1 a}, \mathbf{1 b}, \mathbf{1 c}, \mathbf{5 a}$, and $\mathbf{5 b}$, which were calculated from NBO population analyses, are given in the supplement. This material is available free of charge via the Internet at http://pubs.acs.org. CCDC-723192 (1), 723197 (2), 723195 (3), 723194 (4), 723193 (5), 723196 (6) contain the supplementary crystallographic data for this paper. These data can be obtained free of charge from The Cambridge Crystallographic Data Centre via www.ccdc.cam.ac.uk/data_request/cif.

\section{Acknowledgments}

S. Schulz thanks the German Science Foundation (DFG) for financial support.

[1] L. Bourget-Merle, M. F. Lappert, J. R. Severn, Chem. Rev. 2002, 102, 3031.

[2] P. J. Bailey, S. Pace, Coord. Chem. Rev. 2001, 214, 91.

[3] (a) J. Barker, M. Kilner, Coord. Chem. Rev. 1994, 133, 219. (b) P. C. Junk, M. L. Cole, Chem. Commun. 2007, 1579. For a very recent recent review on amidinate and guanidinate complexes see: (c) F Edelmann, Adv. Organomet. Chem. 2008, 57, 183. The coordination chemistry of neutral amidines and guanidines was recently described: (d) M. P. Coles, J. Chem. Soc., Dalton Trans. 2006, 985.

[4] See for further bindings modes: P. C. Junk, M. L. Cole, Chem. Commun. 2007, 1579.

[5] (a) C. Cui, H. W. Roesky, H.-G. Schmidt, M. Noltemeyer, H. Hao, F. Cimpoesu, Angew. Chem., Int. Ed. Engl. 2000, 39, 4274. (b) N. J. Hardman, B. E. Eichler, P. P. Power, Chem. Commun. 2000, 1991. (c) C. Jones, P. C. Junk, J. A. Platts, A. Stasch, J. Am. Chem. Soc. 2006, 128, 2206. (d) G. Jin, C. Jones, P. C. Junk, A. Stasch, W. D. Woodul, New J. Chem. 2008, 32, 835.

[6] S. P. Green, C. Jones, A. Stasch, Science 2007, 318, 1754.

[7] See the following and references cited therein: (a) M. Stender, A. D. Phillips, P. P. Power, Inorg. Chem. 2001, 40, 5314. (b) S. P. Green, C. Jones, P. C. Junk, K.-A. Lippert, A. Stasch, Chem. Commun. 2006, 3978. (c) A. Stasch, C. M. Forsyth, C. Jones, P. C. Junk, New J.
Chem. 2008, 32, 829. (d) S. Nagendran, S. S. Sen, H. W. Roesky, D Koley, H. Grubmüller, A. Pal, R. Herbst-Irmer, Organometallics 2008, 27, 5459 .

[8] (a) S. Schulz, M. Nieger, Angew. Chem. 1999, 111, 1020; Angew. Chem. Int. Ed. 1999, 38, 967. (b) A. Kuczkowski, S. Schulz, M Nieger, Organometallics 2001, 20, 2000. (c) A. Kuczkowski, S Schulz, M. Nieger, Angew. Chem. 2001, 113, 4351; Angew. Chem. Int. Ed. 2001, 40, 4222.

[9] (a) C. Ergezinger, F. Weller, K. Dehnicke, Z. Naturforsch. B, Chem Sci. 1988, 43, 1119. (b) U. Patt-Seibel, U. Müller, C. Ergezinger, B. Borgsen, K. Dehnicke, D. Fenske, G. Baum, Z. Anorg. Allg. Chem. 1990, 582, 30. (c) P. J. Bailey, R. O. Gould, C. N. Harmer, S. Pace, A. Steiner, D. S. Wright, J. Chem. Soc. Chem. Commun. 1997, 1161. (d) C. L. Raston, R. W. Skelton, V.-A. Tolhurst, A. H. White, Polyhedron 1998, 17, 935. (e) C. L. Raston, B. W. Skelton, V. A Tolhurst, A. H. White, J. Chem. Soc. Dalton Trans. 2000, 1279. Moreover, several boramidinate complexes and complexes with the group 15 element in the formal oxidation state +5 have been structurally characterized: (f) J. Konu, M. S. Balakrishna, T. Chivers, T. W. Swaddle, Inorg. Chem. 2007, 46, 2627. (g) F. Weller, J. Pebler, K. Dehnicke, K. Hartke, H.-M. Wolff Z. Anorg. Allg. Chem. 1982, 486, 61. (h) W. Honeise, W. Schwarz, G. Heckmann, A. Schmidt, Z. Anorg. Allg. Chem. 1986, 533, 55.

[10] S. P. Green, C. Jones, G. Jin, A. Stasch, Inorg. Chem. 2007, 46, 8.

[11] M. Brym, C. M. Forsyth, C. Jones, P. C. Junk, R. P. Rose, A. Stasch, D. A. Turner, J. Chem. Soc. Dalton Trans. 2007, 3282.

[12] (a) L. A. Lesikar, A. F. Richards, J. Organomet. Chem. 2006, 691 , 4250. (b) L. W. Pineda, V. Jancik, S. Nembenna, H. W. Roesky, $Z$. Anorg. Allg. Chem. 2007, 633, 2205. In addition, complexes containing dianionic diamidonapthole substituents have been prepared: (c) H. A. Spinney, I. Korobkov, G. A. DiLabio, G. P. A Yap, D. S. Richeson, Organometallics 2007, 26, 4972. (d) H. A. Spinney, I. Korobkov, D. S. Richeson, Chem. Commun. 2007, 1647.

[13] P. B. Hitchcock, M. F. Lappert, G. Li, A. V. Protchenko, Chem Commun. 2009, 428.

[14] W. Honeise, W. Schwarz, G. Heckmann, A. Schmidt Z. Anorg. Allg. Chem. 1986, 533, 55.

[15] F. Weller, J. Pebler, K. Dehnicke, K.; Hartke, H.-M. Wolff Z. Anorg Allg. Chem. 1982, 486, 61.

[16] According to a structure search in the Cambridge Structural Database, as described anions typically show bridging $\mathrm{Sb}-\mathrm{Cl}$ bond lengths ranging from $3.00-3.30 \AA$.

[17] (a) C. L. Raston, B. W. Skelton, V.-A. Tolhurst, A. H. White, J. Chem. Soc. Dalton Trans. 2000, 1279. (b) C. L. Raston, B. W. Skelton, V.-A. Tolhurst, A. H. White, Polyhedron 1998, 935.

[18] DFT calculations were carried out with the Gaussian03 suite of programs (M.J. Frisch, et al. Gaussian 03, Revision D.02; Gaussian Inc.: Pittsburgh, PA, 2003, complete reference is given in the supplement). The molecular structures and energies of compounds $\mathbf{1 a}, \mathbf{1 b}, \mathbf{1 c}, \mathbf{5 a}$, and $\mathbf{5 b}$ were obtained by performing a complete energy optimization of all geometric parameters at the b3lyp/sdd level (input keywords "\# b3lyp/sdd opt pop=nbo"), using the atomic coordinate of the crystal structure determination of $\mathbf{1}$ and $\mathbf{5}$ (without solvent molecule) as starting point. Population analysis was carried out with the NBO module as implemented in Gaussian03. The final molecular structures and list of the final atomic coordinates and energies, selected bond distances, and NBO atomic populations are given in the electronic supplement.

[19] G. M. Sheldrick, SHELXS-97, Program for Structure Solution: Acta Crystallogr. Sect. A 1990, 46, 467.

[20] G. M. Sheldrick, SHELXL-97, Program for Crystal Structure Refinement, Univ. Göttingen, 1997.

Received: ((will be filled in by the editorial staff)) Published online: ((will be filled in by the editorial staff)) 
Table 1. Selected bond lengths $(\AA)$ and angles $(\mathrm{deg})$ of $t$-BuC(NR) $)_{2} \mathrm{SbCl}_{2}\left(\mathrm{R}=i-\mathrm{Pr} \mathbf{1}, \mathrm{Cy}\right.$, Dipp 3) and $n-\mathrm{BuC}(\mathrm{N} i-\mathrm{Pr})_{2} \mathrm{SbCl}{ }_{2} 4$ and $t-\mathrm{BuC}(\mathrm{NR})_{2} \mathrm{BiCl}{ }_{2}(\mathrm{R}=i-$ Pr 5, Dipp 6)

\begin{tabular}{|c|c|c|c|c|c|c|}
\hline & 1 & 2 & 3 & 4 & 5 & 6 \\
\hline \multirow[t]{2}{*}{ E1-N1 / E1-N2 } & $2.1011(16) /$ & $2.2204(17) /$ & $2.104(2) /$ & $2.205(3) / 2.116(2)$ & $2.236(5) / 2.243(5)$ & $2.408(3) / 2.265(3)$ \\
\hline & $2.1906(17)$ & $2.1022(16)$ & $2.3059(19)$ & & & \\
\hline $\mathrm{E} 1-\mathrm{Cl1} / \mathrm{E} 1-\mathrm{Cl} 2$ & $2.6435(6)$ & $2.3982(6)$ & $2.4732(7)$ & $2.4127(9)$ & $2.6868(18)$ & $2.6171(10)$ \\
\hline \multirow[t]{2}{*}{$\mathrm{E} 1-\mathrm{Cl} 1 / 2 \mathrm{a}$} & $3.1171(7) /$ & $3.2447(6) /$ & $>8.5$ & $3.1195(9) /$ & $3.1746(17) /$ & $3.4398(10) /$ \\
\hline & $4.7343(7)$ & $6.5652(6)$ & & $3.8972(12)$ & $3.2102(19)$ & $6.4022(12)$ \\
\hline C1-N1 / C1-N2 & $1.352(2) / 1.320(2)$ & $1.320(3) / 1.366(3)$ & $1.361(3) / 1.323(3)$ & $1.319(4) / 1.346(4)$ & $1.336(8) / 1.337(8)$ & $1.316(5) / 1.341(5)$ \\
\hline $\mathrm{C} 1-\mathrm{C}_{R}$ & $1.536(3)$ & $1.540(3)$ & $1.543(3)$ & $1.499(5)$ & $1.554(9)$ & $1.561(5)$ \\
\hline $\mathrm{N} 1-\mathrm{C}_{R^{\prime}} / \mathrm{N} 2-\mathrm{C}_{R^{\prime}}$ & $1.469(2) / 1.470(3)$ & $1.461(3) / 1.469(3)$ & $1.437(3) / 1.430(3)$ & $1.460(4) / 1.470(4)$ & $1.464(7) / 1.466(8)$ & $1.422(5) / 1.438(5)$ \\
\hline N1-E1-N2 & $60.69(6)$ & $60.41(6)$ & $59.21(8)$ & $60.99(10)$ & $58.43(18)$ & $55.69(11)$ \\
\hline $\mathrm{N} 1-\mathrm{C} 1-\mathrm{N} 2$ & $108.56(16)$ & 108.29(18) & $109.0(2)$ & $110.8(3)$ & $109.8(5)$ & $110.8(3)$ \\
\hline Cl1-E1-Cl2 & $88.02(2)$ & $87.65(2)$ & $90.27(3)$ & $95.49(7)$ & $175.02(5)$ & $89.05(4)$ \\
\hline C11-E1-N1 / Cl1- & $94.90(5) / 88.02(5)$ & $153.58(5) /$ & $98.89(6) / 88.48(6)$ & $152.19(8) /$ & $84.94(15) /$ & $89.90(9) / 97.14(9)$ \\
\hline Cl2-E1-N1 / Cl2- & $92.55(5) /$ & $87.41(5) / 97.07(5)$ & $89.29(6) /$ & $92.30(8) / 93.12(7)$ & $90.60(15) /$ & $141.99(8) /$ \\
\hline E1-N2 & $152.46(5)$ & & $147.81(6)$ & & $89.31(14)$ & $86.78(9)$ \\
\hline
\end{tabular}

Table 2. Selected bond lengths $(\AA)$ and angles $(\mathrm{deg})$ of the calculated structures of $t$ - $\mathrm{BuC}\left(\mathrm{N} i-\mathrm{Pr}_{2} \mathrm{ECl}_{2}(\mathrm{E}=\mathrm{Sb} \mathrm{1,} \mathrm{Bi} \mathrm{5)}\right.$

\begin{tabular}{|c|c|c|c|c|c|}
\hline & E-N & E-Cl & C-N & Cl-E-Cl & N-E-N \\
\hline 1 (XRD) & $\begin{array}{l}2.1011(16) / \\
2.1906(17)\end{array}$ & $\begin{array}{l}2.4030(6) / 2.6435(6) / \\
3.1171(7) / 4.7343(7)\end{array}$ & $1.352(2) / 1.320(2)$ & $88.02(2)$ & $60.69(6)$ \\
\hline $1 \mathbf{a}(\mathrm{SDD})$ monomer & $2.13 / 2.28$ & $2.50 / 2.60$ & $1.34 / 1.39$ & 91 & 64 \\
\hline $\mathbf{1 b}(\mathrm{SDD})$ trimer & $2.13 / 2.23$ & $\begin{array}{l}2.52 / 2.74 / 3.41 / \\
4.56\end{array}$ & $1.34 / 1.38$ & 90 & 61 \\
\hline $1 \mathbf{c}(\mathrm{SDD})$ trimer $^{[\mathrm{a}]}$ & $2.16 / 2.18$ & $\begin{array}{l}2.76 / 2.76 / 3.16 / \\
3.21\end{array}$ & $1.36 / 1.37$ & 177 & 61 \\
\hline $5(\mathrm{XRD})$ & $2.236(5) / 2.243(5)$ & $\begin{array}{l}2.7399(18) / \\
2.6868(18) / \\
3.1746(17) / \\
3.2102(19)\end{array}$ & $1.336(8) / 1.337(8)$ & $175.02(5)$ & $58.43(18)$ \\
\hline $\mathbf{5 a}(\mathrm{SDD})$ monomer & 2.24 & 2.69 & $1.36 / 1.37$ & 165 & 58 \\
\hline $\mathbf{5 b}(\mathrm{SDD})$ trimer & $2.28 / 2.30$ & $\begin{array}{l}2.81 / 2.83 / 3.03 / \\
3.06\end{array}$ & $1.36 / 1.37$ & 179 & 58 \\
\hline
\end{tabular}

[a] Structure optimization using the structural parameter of the Bi complex (monomeric unit). 
Table 3. Crystallographic data for $t-\mathrm{BuC}(\mathrm{NR})_{2} \mathrm{SbCl}_{2}\left(\mathrm{R}=i\right.$ - $\mathrm{Pr}$ 1, Cy 2, Dipp 3), $n-\mathrm{BuC}\left(\mathrm{N} i-\mathrm{Pr}_{2} \mathrm{SbCl}_{2} 4\right.$ and $t-\mathrm{BuC}(\mathrm{NR})_{2} \mathrm{BiCl}_{2}(\mathrm{R}=i-\mathrm{Pr}$ 5, $\mathrm{Dipp}$ 6)

\begin{tabular}{|c|c|c|c|c|c|c|}
\hline & 1 & 2 & 3 & 4 & 5 & $6^{[\mathrm{d}]}$ \\
\hline empirical formula & $\mathrm{C}_{11} \mathrm{H}_{23} \mathrm{Cl}_{2} \mathrm{~N}_{2} \mathrm{Sb}$ & $\mathrm{C}_{17} \mathrm{H}_{31} \mathrm{Cl}_{2} \mathrm{~N}_{2} \mathrm{Sb}$ & $\begin{array}{l}\mathrm{C}_{29} \mathrm{H}_{43} \mathrm{Cl}_{2} \mathrm{~N}_{2} \mathrm{Sb} \mathrm{x} \\
2 \mathrm{CHCl}_{3}\end{array}$ & $\begin{array}{l}\mathrm{C}_{11} \mathrm{H}_{23} \mathrm{Cl}_{2} \mathrm{~N}_{2} \mathrm{Sb} \times \\
\mathrm{CHCl}_{3}\end{array}$ & $\begin{array}{l}\mathrm{C}_{22} \mathrm{H}_{46} \mathrm{Bi}_{2} \mathrm{Cl}_{4} \mathrm{~N}_{4} \mathrm{X} \\
4 \mathrm{CHCl}_{3}\end{array}$ & $\begin{array}{l}\mathrm{C}_{29} \mathrm{H}_{43} \mathrm{Cl}_{2} \mathrm{~N}_{2} \mathrm{Bi} \mathrm{x} \\
3\left[\mathrm{C}_{4} \mathrm{H}_{8} \mathrm{O}\right]\end{array}$ \\
\hline molecular mass & 375.96 & 456.09 & 851.04 & 495.33 & 1403.86 & 915.85 \\
\hline crystal system & monoclinic & monoclinic & orthorhombic & triclinic & triclinic & monoclinic \\
\hline space group & $\mathrm{P} 2_{1} / \mathrm{c}$ & $\mathrm{P} 2_{1} / \mathrm{n}$ & Pna $_{1}$ & P-1 & $\mathrm{P}-1$ & $\mathrm{P} 2_{1} / \mathrm{n}$ \\
\hline $\mathrm{a}[\AA]$ & $8.9840(2)$ & $12.2083(5)$ & $27.852(5)$ & $8.4646(9)$ & $8.5021(5)$ & $15.0780(3)$ \\
\hline $\mathrm{b}[\AA]$ & $21.4667(6)$ & $8.4120(5)$ & $15.962(3)$ & $10.2032(11)$ & $11.4961(7)$ & $21.7447(5)$ \\
\hline $\mathrm{c}[\AA]$ & $8.6151(2)$ & $19.7778(8)$ & $8.6085(15)$ & $13.1082(15)$ & $13.2404(9)$ & $15.4864(3)$ \\
\hline$\alpha[\mathrm{deg}]$ & 90 & 90 & 90 & $91.661(6)$ & $102.238(4)$ & 90 \\
\hline$\beta[\mathrm{deg}]$ & $111.8150(10)$ & $99.946(3)$ & 90 & $96.985(6)$ & $104.223(4)$ & $111.3847(12)$ \\
\hline$\gamma[\mathrm{deg}]$ & 90 & 90 & 90 & $113.195(5)$ & $98.007(3)$ & 90 \\
\hline $\mathrm{V}\left[\AA^{3}\right]$ & $1542.50(7)$ & $2000.58(17)$ & $3827.1(12)$ & 1029.2(2) & $1200.68(13)$ & $4727.90(17)$ \\
\hline $\mathrm{Z}$ & 4 & 4 & 4 & 2 & 1 & 4 \\
\hline $\mathrm{T}[\mathrm{K}]$ & $193(2)$ & $173(2)$ & $173(1)$ & $173(2)$ & $173(1)$ & $173(1)$ \\
\hline radiation $\lambda[\AA]$ & 0.71073 & 0.71073 & 0.71073 & 0.71073 & 0.71073 & 0.71073 \\
\hline$\mu\left[\mathrm{mm}^{-1}\right]$ & 2.115 & 1.646 & 1.303 & 1.983 & 8.233 & 3.875 \\
\hline $\mathrm{D}_{\text {calcd. }}\left[\mathrm{g} \mathrm{cm}^{-3}\right]$ & 1.619 & 1.514 & 1.477 & 1.598 & 1.942 & 1.287 \\
\hline $2 \theta_{\max }[\mathrm{deg}]$ & 61.0 & 55.8 & 58.9 & 57.1 & 52.8 & 55.0 \\
\hline cryst. $\operatorname{dim}[\mathrm{mm}]$ & $0.26 \times 0.23 \times 0.21$ & $0.31 \times 0.13 \times 0.12$ & $0.36 \times 0.18 \times 0.16$ & $0.34 \times 0.25 \times 0.18$ & $0.17 \times 0.13 \times 0.07$ & $0.27 \times 0.22 \times 0.13$ \\
\hline no. of reflns. & 39764 & 34204 & 75324 & 20366 & 24247 & 72955 \\
\hline no. uniq. reflns. & 4529 & 4603 & 10336 & 5042 & 5935 & 13170 \\
\hline$R_{\text {merg }}$ & 0.0262 & 0.0708 & 0.0590 & 0.0351 & 0.0658 & 0.0670 \\
\hline $\begin{array}{l}\text { no. of param. } \\
\text { ref./restraints }\end{array}$ & $146 / 0$ & $200 / 0$ & $391 / 1$ & $209 / 0$ & $218 / 0$ & $514 / 0$ \\
\hline$R 1^{[\mathrm{a}]}$ & 0.0237 & 0.0266 & 0.0309 & 0.0399 & 0.0447 & 0.0370 \\
\hline$w R 2^{[\mathrm{b}]}$ & 0.0516 & 0.0688 & 0.0714 & 0.893 & 0.1138 & 0.1012 \\
\hline goodness of fit ${ }^{[c]}$ & 1.335 & 1.027 & 0.993 & 1.037 & 1.008 & 1.038 \\
\hline $\begin{array}{l}\text { final max } / \min . \Delta \rho \text {, } \\
\text { e } \AA^{-3}\end{array}$ & $0.526 /-1.056$ & $0.533 /-0.848$ & $0.628 /-0.660$ & $1.030 /-0.899$ & $3.326 /-3.863$ & $2.472 /-0.763$ \\
\hline
\end{tabular}

[a] $R 1=\Sigma\left(|| F_{\mathrm{o}}|-| F_{\mathrm{c}} \|\right) / \Sigma\left|F_{\mathrm{o}}\right|($ for $\mathrm{I}>2 \sigma(\mathrm{I})) .-[\mathrm{b}] w R 2=\left\{\Sigma\left[w\left(F_{\mathrm{o}}^{2}-F_{\mathrm{c}}{ }^{2}\right)^{2}\right] / \Sigma\left[w\left(F_{\mathrm{o}}^{2}\right)^{2}\right]\right\}^{1 / 2} .-[\mathrm{c}]$ Goodness of fit $=\left\{\Sigma\left[w\left(\left|F_{\mathrm{o}}{ }^{2}\right|-\left|\mathrm{F}_{\mathrm{c}}{ }^{2}\right|\right)^{2}\right] /\left(\mathrm{N}_{\mathrm{observns}}-\mathrm{N}_{\mathrm{params}}\right)\right\}^{1 / 2} .-[\mathrm{d}] t-$ Bu carbon atoms $C(27)$ to $C(29)$ disordered over two sites with SOF 0.5 , THF molecules $O(60), C(60)$ to $C(63)$ and $O(70), C(70)$ to $C(73)$ refined with reduced SOF 0.5 together with the riding hydrogen atoms. In spite of the reduced SOFs of the solvent molecules, the ADPs still indicate severe disorder which could not be resolved. 


\section{Entry for the Table of Contents}

\section{Layout 1:}

Amidinate Complexes

$\mathrm{X}$-Ray crystal structures of six amidinate complexes [RC(NR') $\left.{ }_{2}\right] \mathrm{ECl}_{2}$ of the heaviest group 15 metals (Sb, Bi) clearly reveal the distinguished influence of both the metal atom and the amidinate substituent to the coordination geometry of the resulting complexes.

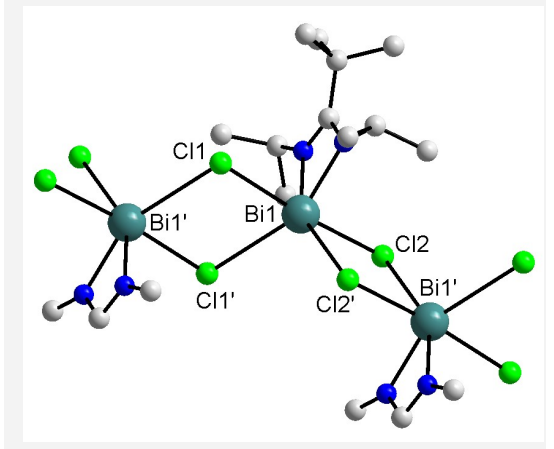

Benjamin Lyhs, Stephan Schulz, * Ulrich Westphal, Dieter Bläser,

Roland Boese, Michael Bolte,

Page No. - Page No.

Heteroleptic Amidinate Complexes of Heavy Group 15 Elements - Synthesis, $\mathrm{X}$-Ray Crystal Structures and

Theoretical Calculations

Keywords: N ligands / Main group elements / Antimony / Bismuth / X-Ray diffraction 
This text is made available via DuEPublico, the institutional repository of the University of Duisburg-Essen. This version may eventually differ from another version distributed by a commercial publisher.

DOI: $\quad 10.1002 /$ ejic.200900233

URN: ｕrn:nbn:de:hbz:464-20201030-103913-3

This is the peer reviewed version of the following article: Eur. J. Inorg. Chem. 2009, 2247-2253, which has been published in final form at:

https://doi.org/10.1002/ejic.200900233

All rights reserved. 